\title{
ENHANCING MARITIME SECURITY COOPERATION
}

\section{Lutfi Saefullah,}

Doctor in Public Administration, Universitas Negeri Makassar (UNM), Makassar, Indonesia

Husain Syam,

Rector of Universitas Negeri Makassar (UNM), Makassar, Indonesia

Hamsu Abdul Gani,

Director of Post-Graduate Program UNM, Makassar, Indonesia

Haedar Akib,

Chairman of Administration Science Department, Faculty of Social Science, UNM, Makassar, Indonesia

\begin{abstract}
Seaborne trade is an important component of world trade by which, Indonesia's water becomes very important and vital in contributing to the world economy. Notwithstanding the strategic meaning of Indonesian water to the World, Indonesian water is still the full responsibility of Indonesia. Indonesia has made substantial and sustained efforts to maintain the safety and security of its sea lanes of communication by updating paper charts, installing navigational aids, broadcasting maritime hazards and weather forecasts, and patrolling certain areas. These efforts show that Indonesia, somewhat, has undertaken its obligations in taking care of the international community interests. Nevertheless, user states and other ships which use chokepoints within Indonesia' water and derive significant benefits within sometimes do not realize as such. Therefore, this article on the results of normative research aims to explain the need to increase maritime security cooperation as a precondition for achieving the common goals of countries that utilize Indonesian waters and surrounding countries as a route of transportation, trade, cultural exchange, science and civilization.
\end{abstract}

Article Received: 18 October 2020, Revised: 3 November 2020, Accepted: 24 December 2020

\section{Introduction}

Indonesian water is bordered by 10 countries and as such is most likely to create dynamic maritime issues in maritime security cooperation (Bradford, 2005; Chapsos \& Malcolm, 2017; Gindarsah \& Priamarizki, 2015). To manage the issues along with securing the national interest, the Government of Indonesia has taken decisive steps in defence policy, in particular international cooperation which leads to a form of cooperation with the principle of mutual respect, benefit, and trust on maritime security. Indonesia has taken steps to enhance maritime security such as maritime security patrol, either individually (Indonesia Navy, Air force and other government's ships for non-commercial purpose on entire Territorial water \& EEZ) or through coordinated patrol with neighbouring countries, bilaterally and multilaterally with adjacent littoral states.

As a form of library research combined with observations and interviews with informants, the methods used are "normative legal research" (Christiani, 2016; Taekema, 2018) and descriptive research . Normative legal research is carried out by reviewing library materials or reconstructing research results and experts' thoughts based on secondary data. According to Soekanto \& Mamudji (1985), normative legal research or library research is a study of documents, using various secondary data, such as statutory regulations, court decisions, legal theory, and also in the form of expert opinions. While the descriptive method is used to describe the reality as it is while still emphasizing the presentation of empirical evidence supported by data and information from interviews as a rationale for the need for maritime security improvement-based cooperation. This also describes success stories and lessons learned in turning challenges and threats into opportunities for mutually beneficial cooperation based on the trust of all parties involved. 


\section{Model on Cooperation in the field of operations that have taken action}

Maritime security improvement requires cooperation among countries in the framework of security (Bradford, 2005; Marlow, 2010). The basic principle of cooperation is mutual trust and benefit (Buntoro, 2018). Maritime Security cooperation must always adhere to the national interests of all countries and implement a Counter Balancing Interest. Cooperation in securing the sea is a form of cooperation which put forward constructivism, securitization, and human security (Christie, 2010; Hama, 2017; Maclean, 2008). Such cooperation may include security cooperation activities in the form of coordinated patrol in fields and regular joint coordinating meeting in dealing with various forms of maritime security issues.

The Malacca Straits Patrols Joint Coordinating Committee (MSP-JCC) is established in 2006 as the channel of communication and coordination for all activities and issues on Malacca straits and Singapore straits security matters implemented by the respective Armed Forces of participating littoral states adjacent, Indonesia, Malaysia, Singapore and Thailand (Sawhney, 2006; Simon, 2011). The MSP JCC encompasses a range of activities, from operational-level cooperation and assessment to planning and executing the coordinated Malacca Straits Sea Patrols (MSSP) and Eye in the Sky (EiS) as combined maritime air patrols (Akib \& Hariyono, 2019) and supporting by intelligent exchange group (IEG). The formal MSP JCC meeting is to be held once a year, at alternating venues in 4 participating littoral states. In tactical level, the meeting either Sea Patrols Joint working group (MSSP JWG), EiS Joint Working Group (EiS JWG) and EIG are held every four months at the alternating venues. These working groups have a responsibility to develop the instructions on coordination and communications procedures among the Task Group Units in conducting the coordinated sea patrols, combine maritime air patrols and intelligence and information exchange in support of the conduct MSSP and EiS. In the tactical level, Task Group Units taking actions on maintain and secure along the straits. They do identification, visit and search, capture all offender especially hijacker.

Apart from regional cooperation, Indonesia armed forces and its neighbouring countries have established bilateral cooperation on maritime security from the joint field, tactical, up to the policy of operation level. The framework of that Cooperation places Joint Committee to have a responsible assessment and conduct on annual meeting at least, regularly and followed by the tactical meeting. With India on Indindo Corpat (Coordinated Patrol), with Thailand on Thaenisia Corpat, with Malaysia on Malindo Corpat, with Singapore on Indosin Corporate, with Philipphina on Philindo Corpat and with Australia on Ausindo Corpat. In the higher level, there were also regular Joint Defence and Security dialogue (between Chief of Navy level, Assistance C-in-C for Operations and Intelligence, $\mathrm{C}$-in-C level and Ministerial level).

The important thing to be underlined is that the conduct of regular meeting and assessment, as well as coordinate patrol using military aircraft (Akib \& Hariyono, 2019; Hariyono, Akib, \& Rifdan, 2018; Haryono, Akib, Sjarief, \& Paraga, 2019) and supported by intelligence, create such comprehensive maritime security that in turn, they may ensure the regional security and stability (Febrica, 2017; Potgieter, 2012; Simon, 2011; Storey, 2009). Both of them, bilateral and regional cooperation, supplement to each other for a better result on-field operations. Of course, the cooperation in the field cannot be done successfully without high technology support; such as the establishment of the Traffic Separation Scheme (TSS), Vessel Traffic Systems (VTS), the Straits of Malacca Ship Reporting System (STRAITREP), Integrated Maritime Surveillance Systems (IMSS), Surface Picture (SURPIC), Global Maritime Distress and Safety System (GMDSS) and an enhanced-naval base along the Straits (Saefullan, 2021).

Cooperation can also be done in the form of enhancing information superiority (Febrica, 4770 
2017). They are to include; to exchange information and to build integrated information systems between countries, including the completeness of surveillance and monitoring system; to carry out joint exercises, such as antisea robbery exercises; to enhance navigation aids; to assist the development of capabilities on maritime security, in particular providing facilities for training. Besides, the real action civic mission in helping the community along the coast can be explored through enhancing the education, health and prosperity therein. Since occasionally there are also some impacts coming from oil pollution of which they bother the daily living and cannot be reached by any development due to the difficulties of communication.

Also, as cooperation grows stronger and frequently, the trend of incidents declines (Storey, 2009). As such is most likely to come from the numerous presences of naval when doing their joint exercises or coordinated patrols. Or it may also come from the broadcastings that there will be exercises or coordinated operations on those areas. In the bigger picture, it is strategically beneficial as it prevents any sea crime - either sea robbery on the territorial waters and EEZ or piracy on the high seas; to happen.

\section{Some Success Stories}

The declining of sea robbery incidence. Comprehensive maritime security Cooperation turn may ensure regional security and stability. This is can be observed in the decline of the sea robbery incidence and attacks against shipping in the vicinity of Indonesian waters in recent times. For example, the International Maritime Bureau (IMB) reported in 2008 that there were only two incidents which occurred in the Straits of Malacca and Singapore. In 2008 there were only four incidents have been reported which occurred in Indonesian waters compared with nine incidents in 2007 and 19 incidents in 2006 (Hribernik, 2013; Pomeroy, Parks, Mrakovcich, \& LaMonica, 2016).

MV Keraton (2007). Details of the Incident. The ship departed Palembang (Indonesia) for
Cilacap (Indonesia) at $1315 \mathrm{hrs}$ (local time) on 22 Sep 07 with a cargo of vegetable oil on board. At 2050hrs (local time), the shipmaster reported to Tanjung Buyut pilot station in Palembang that several robbers had boarded the ship at $00^{\circ} 03.6^{\prime}$ S, $105^{\circ} 16.2^{\prime} \mathrm{E}$ (about $40 \mathrm{~nm}$ south-east of Bintan island). Based on the ship's tracking system, the shipowner believed that the robbers were sailing the vessel to either Singapore or Malaysia. On 24 Sep 07 at $0930 \mathrm{hrs}$ (local time), the Indonesian authorities boarded the MV Kraton south of Tanjung Ayam, Johor, and detained fourteen robbers on board the ship for further investigation. The seventeen crew members were safe and the cargo of vegetable oil remained intact on board the ship. Comments by ReCAAP: The ReCAAP ISC notes the quick response of the Indonesian authorities in responding to this incident. The incident depicted that the number of ships involved as well as their presence at the sea determined the outcome of the operation. Upon this particular case, it is indicated that Indonesian authorities (Indonesian Navy) have prepared itself at any time to be ready to conduct the counter-sea robbery (Greenblatt, 2010).

Sinar Kudus Incident (2011). Details of the Incident. On 16 ${ }^{\text {th }}$ March 2011, an Indonesia flagged ship, Sinar Kudus, was hijacked by Somali pirates. The ship was brought to $200 \mathrm{~km}$ off the coast, $500 \mathrm{~km}$ away south from her previous position (Apriani, 2021). In the beginning, Indonesia Government chose negotiation with the pirate, yet military operation was also an option. While the negotiation was underway, Indonesia deployed almost 400 TNI personnel including 100 commandos from its Navy and Army to its forward operating base in Oman, using TNI-AU Boeing and Landing Platform Dock (Indonesia Naval Ship). After 46 days in captivity, finally, the pirates agreed with the amount of ransom and release the hostages. Yet, after the cash was dropped, another pirates group appeared tried to take the ship. The Indonesian military took action to prevent by launching two small Sea Rider crafts, with commandos on board, from the KRI "Abdul 
Halim" to intercept this second group. The commandos were able to re-capture the ship, killing four in a gunfire exchange. Comments: The Sinar Kudus Incident portrays Indonesia strong will to deal with piracy although it had to project a significant number of its military force elements (Army, Navy and Air force) far beyond the state boundary.

Product tanker Ai Maru (2014). Details of the Incident. On 14 Jun 14, the shipping company reported to the ReCAAP ISC that Honduras registered product tanker $A i$ Maru, IMO no. 7809182 with 1520 metric tonne of MGO departed western OPL Singapore for the Gulf of Thailand. At or about $2030 \mathrm{hrs}$ she was boarded by an unknown number of robbers from threespeed boats at $02^{\circ} 06.90^{\prime} \mathrm{E}, 104^{\circ} 39.80^{\prime} \mathrm{E}$ (South China Sea). The vessel then turned and headed on a south-easterly course at about 6.5 knots (Ali \& Apandi, 2016). Responses by the Indonesian Navy (TNI-AL) and other Regional Enforcement Agencies. The surrounding states deployed six vessels to the location: one ship from the Royal Malaysian Navy (RMN), two ships from the Malaysian Maritime Enforcement Agency (MMEA), two ships from the TNI-AL and one ship from the Republic of Singapore Navy (RSN). Malaysian maritime enforcements vessel had proceeded alongside the Ai Maru for investigation.

Comments by ReCAAP ISC: The same vessel, Ai Maru had been boarded by pirates in 2012 in the South China Sea with the same intention of siphoning. However, the pirates' plan was foiled when the authorities were in the vicinity. This time around, the pirates' plan was again foiled owing to the quick response from regional maritime authorities. The ReCAAP ISC commends the shipping company for the timely reporting and the regional authorities from Singapore, Malaysia and Indonesia for the cooperation and coordinated operation responses and would once again emphasize the need for timely information sharing as well as proper information management. Such a collaborative effort between the industry and enforcement agencies has prevented a possible case of piracy/fuel siphoning crime at sea.

\section{Discussion}

Lesson Learned. Based on the significant contribution for safeguarding the straits, the Malacca Straits Patrol Cooperation (MSPC) offers some lessons to be learned. These lessons are useful not only for the future MSPC but also for other maritime security cooperation in the region. Such learning could enhance current expertise and create new guidance. Others could avoid the same failures in future operations and achieve a better outcome.

The MSPC offered some decent values as follows. The Coastal States agreed to cooperate to achieve safety, security, and regional stability. This partnership also proved beneficial interoperability among the Coastal States, the User States and maritime stakeholder. The User states and maritime stakeholders played a role through a burden-sharing mechanism and capacity building for coastal states. The MSPC also used advanced maritime technology in information sharing to support cooperation at sea more effective. The most significant principle of the Cooperative Mechanism is the recognition of territorial sovereignty and sovereign rights as well as the jurisdiction of the coastal countries (Biersteker, 2002; Griffiths, 2017). This aspect is the basic foundation for cooperation.

Comprehensive Cooperation Mechanism on MSP JCC which the conducting of regular meeting and assessment as well as coordinate patrol using military aircraft and supported by intelligence, create more effective of maritime security cooperation. Individual action over its sovereignty \& EEZ, bilateral and regional cooperation, supplements each other for a better result on the field of operations.

Key Challenges. Moving forward to future maritime security cooperation, some points need to be considered. Those are the challenges: whether they need to be maintained, to progress, but with significant efforts. The key challenges 
are: To build confidence and mutual understanding, smartly, achievable and followed by tangible product to build trust. Some practical examples are port visit and senior officer/student exchange visit; To explore every opportunity in developing cooperation in the context of capacity building, information sharing, logistic support and equipment; Promoting cooperation through activities such information sharing, technological cooperation and exchange of visits of authorities concerned; To promote cooperation in regional and multilateral exercises on maritime security as well as training and educations; Burden sharing on contribution to helping community along the coast in education and other human assistances. Although the littoral states have established such solid cooperation in taking on the safety and security issues within their water, yet it does not mean they close other states' contribution. The littoral states are fully aware that there are also other means of enhancing maritime safety and security that may be outside of their radar. Hence, other states or non-state actors contribution are also welcomed as long as they are given through appropriate channels and are approved by the littoral states.

\section{Conclusion}

Since economy has become the most influential field in the era of globalization, the security of shipping routes has become a crucial issue for many states. The comprehensive cooperation in field can become a good example for other region, honouring mutual interest and paying respect to the other state's sovereignty as well as to the national and international law. Some actions need to be taken by the Coastal States in order to improve their performance and to compel emerging threats in the future. Above all, managing security in the strategic chokepoint is not only about burden sharing at sea but also about "Trust" among participants. Trust is a key of partnership, and like ocean connects the nations, trust connects the peoples who are in charge of collaboration. As trust cannot be surged, it needs time and whole hearts measures in confidence-building among regional countries. Piracy and armed robbery problems cannot be overcome within a short period of time. They are also no certain or even a single country problem. They are long-lasting dilemma which may use up the resources for the long run. Therefore, there is a need for sustained efforts that involve all countries. In fact, the cooperation is paramount. It requires not only real operation to combating piracy or armed robbery in defined areas, but also capacity building by which countries can have adequate capability in handling the issue.

\section{Bibliography}

[1] Akib, H., \& Hariyono, U. S. (n.d.). The Spread Out Strategy of the Main Weapons Tool System of the Indonesian Air Force in the Region of The Republic of Indonesia. AUSTRAL: Brazilian Journal of Strategy \& International Relations, 8(15). https://doi.org/10.22456/2238-6912.83627

[2] Ali, N. N. S., \& Apandi, L. S. A. (2016). Securing Maritime Supply Chain: Threats and Challenges of Piracy and Armed Robbery in Southeast Asian Waters. Kuala Lumpur Malaysia.

[3] Apriani, D. D. (2021). Implementation of State Jurisdiction and Handling of Taxation of Vessels in Indonesian Sea Waters. KnE Social Sciences, 1-16. https://doi.org/10.18502/kss.v5i1.8266

[4] Biersteker, T. J. (2002). State, sovereignty and territory. In Handbook of international relations (pp. 157-176). Sage London.

[5] Bradford, L. J. F. (2005). The growing prospects for maritime security cooperation in Southeast Asia. Naval War College Review, 58(3), 63-86. Retrieved from https://www.jstor.org/stable/pdf/26394205.pd f?refreqid=excelsior\%3Ada90d7fc8c34fd5d7 0a111a4cff10d66

[6] Buntoro, K. (2018). Enhancing Safety and Security in Indonesian Waters: Cooperations Within Diplomacy Framework. Jurnal Pertahanan \& Bela Negara, 4(2), 53-70. https://doi.org/10.33172/jpbh.v4i2.331 
[7] Chapsos, I., \& Malcolm, J. A. (2017). Maritime security in Indonesia: Towards a comprehensive agenda? Marine Policy, 76, 178-184.

https://doi.org/10.1016/j.marpol.2016.11.033

[8] Christiani, T. A. (2016). Normative and Empirical Research Methods: Their Usefulness and Relevance in the Study of Law as an Object. Procedia-Social and Behavioral Sciences, 219, 201-207. https://doi.org/10.1016/j.sbspro.2016.05.006

[9] Christie, R. (2010). Critical voices and human security: To endure, to engage or to critique? Security Dialogue, 41(2), 169-190. https://doi.org/10.1177/0967010610361891

[10] Febrica, S. (2017). Maritime security and Indonesia: Cooperation, interests and strategies. New York: Taylor \& Francis.

[11] Gindarsah, I., \& Priamarizki, A. (2015). Indonesia's maritime doctrine and security concerns. JSTOR. Retrieved from https://www.jstor.org/stable/pdf/resrep05869. pdf

[12] Greenblatt, A. (2010). Attacking Piracy. Issues in Peace and Conflict Studies: Selections From CQ Researcher, 417.

[13] Griffiths, R. D. (2017). Admission to the sovereignty club: The past, present, and future of the international recognition regime. Territory, Politics, Governance, 5(2), 177189.

https://doi.org/10.1080/21622671.2016.1265 463

[14] Hama, H. H. (2017). State security, societal security, and human security. Jadavpur Journal of International Relations, 21(1), 119.

https://doi.org/10.1177/0973598417706591

[15] Hariyono, U. S., Akib, H., \& Rifdan, R. (2018). Bare Base Concept as Alternative Strategies Dealing with Threats in the Air Territory of the Unitary State of the Republic of Indonesia. Jurnal Ilmiah Ilmu Administrasi Publik, $8(1)$, $1-10$. https://doi.org/10.26858/jiap.v8i1.2478

[16] Haryono, U. S., Akib, H., Sjarief, E., \& www.psychologyandeducation.net
Paraga, S. (2019). Decision Stipulation on National Air Space Zone of the Republic of Indonesia. Journal of Legal, Ethical and Regulatory Issues, 22(2), 1-10. Retrieved from

https://search.proquest.com/openview/d0a1fc cede33799a454314d73ad33c2f/1?pq-

origsite $=$ gscholar $\& \mathrm{cbl}=38868$

[17] Hribernik, M. (2013). Countering Maritime Piracy and Robbery in Southeast Asia: The Role of the ReCAAP Agreement. EIAS Briefing Paper, (2013/2). Retrieved from https://papers.ssrn.com/sol3/papers.cfm?abstr act_id $=2342274$

[18] Maclean, S. J. (2008). Microbes, mad cows and militaries: exploring the links between health and security. Security Dialogue, 39(5), 475-494.

https://doi.org/10.1177/0967010608096149

[19] Marlow, P. B. (2010). Maritime security: an update of key issues. Maritime Policy \& Management, 37(7), 667-676. https://doi.org/10.1080/03088839.2010.5247 34

[20] Pomeroy, R., Parks, J., Mrakovcich, K. L., \& LaMonica, C. (2016). Drivers and impacts of fisheries scarcity, competition, and conflict on maritime security. Marine Policy, 67, 94104. https://doi.org/10.1016/j.marpol.2016.01.005

[21] Potgieter, T. D. (2012). Maritime security in the Indian Ocean: strategic setting and features. Institute for Security Studies Papers, 2012(236), 24. Retrieved from https://www.ingentaconnect.com/content/sabi net/ispaper/2012/00002012/00000236/art000 01

[22] Saefullan, L. (2021). Strategi Maritim Security Tentara Nasional Indonesia Angkatan Laut untuk Mendukung Poros Maritim Dunia. Universitas Negeri Makassar.

[23] Sawhney, R. (2006). Redefining the Limits of the Malacca Straits. Maritime Studies, (148), $26 . \quad$ Retrieved from https://search.proquest.com/openview/1190b $7 \mathrm{ab} 84 \mathrm{e} 8 \mathrm{f} 48 \mathrm{c} 477163 \mathrm{c} 4 \mathrm{fe} 26 \mathrm{c} 383 / 1$ ?cbl=54881 
\&pq-origsite $=$ gscholar

[24] Simon, S. W. (2011). Safety and security in the Malacca straits: The limits of collaboration. Asian Security, 7(1), 27-43. https://doi.org/10.1080/14799855.2011.5482 08

[25] Soekanto, S., \& Mamudji, S. (1985). Normative Legal Research. Jakarta, Indonesia: Raja Grafindo Persada.

[26] Storey, I. (2009). Maritime Security in Southeast Asia: Two Cheers for Regional Cooperation. Southeast Asian Affairs, 36-58. Retrieved from https://www.jstor.org/stable/27913377?seq=1

[27] Taekema, S. (2018). Theoretical and normative frameworks for legal research: Putting theory into practice. In Law and Method.

https://doi.org/10.5553/REM/.000031 